\title{
Bosea eneae sp. nov., Bosea massiliensis sp. nov. and Bosea vestrisii sp. nov., isolated from hospital water supplies, and emendation of the genus Bosea (Das et al. 1996)
}

Correspondence

Didier Raoult

didier.raoult@

medecine.univ-mrs.fr

\author{
Bernard La Scola, ${ }^{1}$ Marie-Noëlle Mallet, ${ }^{1}$ Patrick A. D. Grimont ${ }^{2}$ \\ and Didier Raoult ${ }^{1}$ \\ ${ }^{1}$ Unité des Rickettsies, CNRS UPRESA 6020, Faculté de Médecine, Université de la \\ Méditerrannée, 27 Boulevard Jean Moulin, 13385 Marseille Cedex 05, France \\ ${ }^{2}$ Unité des Entérobactéries, Unité INSERM 199, Institut Pasteur, 75724, Paris Cedex 15, \\ France
}

\begin{abstract}
On the basis of phenotypic and DNA relatedness data, three novel species of the genus Bosea are proposed, Bosea massiliensis $\left(63287^{\top}=\right.$ CIP $106336^{\top}=$ CCUG $\left.43117^{\top}\right)$, Bosea vestrisii $\left(34635^{\top}=\right.$ CIP $106340^{\top}=$ CCUG $\left.43114^{\top}\right)$ and Bosea eneae $\left(34614^{\top}=\right.$ CIP $106338^{\top}=$ CCUG $43111^{\top}$ ). The original description of the genus Bosea included thiosulphate oxidation as a phenotypic feature, when the sole and type species of the genus, Bosea thiooxidans, was proposed. The three novel species described herein were not able to oxidize thiosulphate; thus, it is proposed that this characteristic be removed from the description of the genus and considered as specific for $B$. thiooxidans. The novel species of the genus Bosea proposed here form a well-separated cluster in the Bradyrhizobium group of the $\alpha$-2 subclass of the Proteobacteria, on the basis of 16S rDNA gene sequence analysis. However, 16S rDNA gene sequence analysis was not sufficient to delineate the species; hence, DNA-DNA relatedness and phenotypic data were also required. All of the novel species described in this study are fastidious bacteria isolated from a hospital water supply, using co-cultivation with amoebae. This group of bacteria are hypothesized to be a potential cause of nosocomial infections. For treatment of infections caused by these novel bacteria, doxycycline appears to be the sole antibacterial compound with a consistently low MIC value.
\end{abstract}

\section{INTRODUCTION}

Using an amoebal co-cultivation procedure, 68 strains of diverse $\alpha$-Proteobacteria were isolated, including Afipia spp., from hospital water supplies (La Scola et al., 2000). By amplification and sequencing of the $16 \mathrm{~S}$ rRNA genes of these strains, 57 were found to be closely related to Bosea thiooxidans, a bacterium for which the genus and species is represented by a sole isolate, BI- $42^{\mathrm{T}}\left(\mathrm{DSM} 9653^{\mathrm{T}}\right)$, which was isolated from agricultural field soil during a study of chemolithoheterotrophic bacteria(Das et al., 1996). On the basis of phenotypic and genotypic data, we propose that the bacteria recovered from the hospital water system be

The GenBank accession numbers for the 16S rRNA gene sequences of $B$. vestrisii $34635^{\top}$, B. eneae $34614^{\top}$, B. thiooxidans $\mathrm{Bl}-42^{\top}$ and $B$. massiliensis $63287^{\top}$ are AF288306, AF288300, AF508803 and AF288309, respectively.

Fatty acid composition data, antimicrobial susceptibility profiles and sequence similarity data for the strains described in this paper can be found as supplementary data in IJSEM Online (http://ijs.sgmjournals.org). assigned to the genus Bosea as three novel species, for which we propose the names Bosea eneae, Bosea vestrisii and Bosea massiliensis. The characteristics of these novel species are described herein.

\section{METHODS}

Strains. The strains used in this study are listed in Table 1 and have been deposited in the Collection de Souches de l'Institut Pasteur (CIP, Paris, France) and the Culture Collection of the University of Göteborg (CCUG, Göteborg, Sweden). Isolation of these strains has been described previously (La Scola et al., 2000). All strains were subcultured routinely on BCYE agar plates (bioMérieux) at $30{ }^{\circ} \mathrm{C}$ as described previously (La Scola et al., 2000).

Phenotypic tests. The morphological properties of the strains were studied microscopically following Gram- and Gimenez-staining. Oxidase activity was detected using an $N, N$-dimethyl-p-phenylenediamine oxalate disc (Sanofi Diagnostics Pasteur). Catalase activity was detected by emulsifying a colony in $3 \% \mathrm{H}_{2} \mathrm{O}_{2}$ and checking for the presence of microscopic bubbles. Other biochemical tests were performed by inoculation of API $20 \mathrm{NE}$ and API $50 \mathrm{CH}$ 
Table 1. Strains used in this study

\begin{tabular}{|ll|}
\hline Strain & \multicolumn{1}{c|}{ Reference } \\
\hline Bosea thiooxidans $\mathrm{BI}-42^{\mathrm{T}}\left(\mathrm{DSM} 9653^{\mathrm{T}}\right)$ & Das et al. $(1996)$ \\
Bosea massiliensis $63287^{\mathrm{T}}\left(\mathrm{CIP} 106336^{\mathrm{T}}=\mathrm{CCUG} 43117^{\mathrm{T}}\right)$ & La Scola et al. $(2000)$ \\
Bosea massiliensis $34649(\mathrm{CIP} 106337=\mathrm{CCUG} 43116)$ & La Scola et al. $(2000)$ \\
Bosea eneae $34614^{\mathrm{T}}\left(\mathrm{CIP} 106338^{\mathrm{T}}=\mathrm{CCUG} 43111^{\mathrm{T}}\right)$ & La Scola et al. $(2000)$ \\
Bosea eneae $34617(\mathrm{CIP} 106342=\mathrm{CCUG} 43112)$ & La Scola et al. $(2000)$ \\
Bosea vestrisii $34635^{\mathrm{T}}\left(\mathrm{CIP} 106340^{\mathrm{T}}=\mathrm{CCUG} 43114^{\mathrm{T}}\right)$ & La Scola et al. $(2000)$ \\
Bosea vestrisii $34620(\mathrm{CIP} 106341=\mathrm{CCUG} 43113)$ & La Scola et al. $(2000)$ \\
Bosea vestrisii $63286(\mathrm{CIP} 106339=\mathrm{CCUG} 43115)$ & La Scola et al. $(2000)$ \\
\hline
\end{tabular}

strips (bioMérieux) according to the manufacturer's instructions and incubation at $30^{\circ} \mathrm{C}$. These strips were incubated for 7 and 15 days, respectively. The API $20 \mathrm{NE}$ strip tested for nitrate reduction, indole production, urease activity, glucose acidification, arginine dihydrolase activity, hydrolysis of gelatin and aesculin, $\beta$-galactosidase activity and assimilation of glucose, arabinose, mannose, mannitol, $\mathrm{N}$-acetyl-D-glucosamine, maltose, gluconate, caprate, adipate, malate, citrate and phenylacetate. As the interpretation of arginine dihydrolase and gelatinase activities on this strip was difficult, assays for these activities were performed in ADH/ODC/LDC broth (Sanofi Diagnostics Pasteur) and on nutrient gelatin (Oxoid), respectively, according to the manufacturers' instructions with incubation at $30{ }^{\circ} \mathrm{C}$ for 7 days. $\mathrm{H}_{2} \mathrm{~S}$ production was tested using sodium thiosulphate as substrate (bioMérieux) and inoculating the $\mathrm{H}_{2} \mathrm{~S}$ test cup of the API 20E strip (bioMérieux) with bacteria suspended in nutrient broth (NB), with the omission of oil from the cup. $B$. thiooxidans was used as the control. The API $50 \mathrm{CH}$ system tested for any acidification of glycerol, erythritol, D-arabinose, L-arabinose, ribose, D-xylose, L-xylose, adonitol, methyl $\beta$-D-xyloside, galactose, D-glucose, D-fructose, D-mannose, L-sorbose, rhamnose, dulcitol, inositol, mannitol, sorbitol, methyl $\alpha$-D-mannoside, methyl $\alpha$-Dglucoside, $N$-acetyl-D-glucosamine, amygdalin, arbutin, aesculin, salicin, cellobiose, maltose, lactose, melibiose, sucrose, trehalose, inulin, melezitose, D-raffinose, starch, glycogen, xylitol, gentiobiose, D-turanose, D-lyxose, D-tagatose, D-fucose, L-fucose, D-arabitol, L-arabitol, gluconate, 2-keto-D-gluconate and 5-keto-D-gluconate. Growth and haemolysis were tested at $30{ }^{\circ} \mathrm{C}$ on Columbia agar with $5 \%$ sheep blood (bioMérieux), Columbia agar (bioMérieux) enriched with $0.2 \%$ yeast extract (Merck) and $5 \%$ sheep blood, MacConkey's agar (bioMérieux) and NB (Difco), alone or with $6 \%$ $\mathrm{NaCl}$. Growth on BCYE agar was tested at $25,30,35,37$ and $42{ }^{\circ} \mathrm{C}$. The presence of flagella was assessed by depositing bacteria that had been cultured on BCYE agar onto a Formvar film. The bacteria were then stained with a $0.33 \%$ solution of uranylacetate and examined using a JEOL JEM 1200 EX electron microscope.

Antimicrobial susceptibility testing. The strains were grown for $72-96 \mathrm{~h}$ on BCYE agar prior to testing. Antibiotic susceptibility testing was performed using a micro broth-dilution method in NB. For testing of susceptibility to cotrimoxazole, $5 \%$ lysed horse blood was added to the broth. The final inoculum for all broth tests contained between $1 \times 10^{5}$ and $5 \times 10^{5}$ c.f.u. $\mathrm{ml}^{-1}$. The plates were incubated at $30{ }^{\circ} \mathrm{C}$ and read between 72 and $96 \mathrm{~h}$. Escherichia coli (ATCC 25922) and Enterococcus faecalis (ATCC 29212) were used as controls.

Analysis of major proteins using SDS-PAGE. The strains were harvested after 5-7 days cultivation and suspended in deionized water in preparation for SDS-PAGE. SDS-PAGE was performed using the methods described by Laëmmli (1970). Equal volumes of antigen (titrated to $4 \mathrm{mg}$ protein $\mathrm{ml}^{-1}$ ) and sample buffer $[0.0625 \mathrm{M}$ Tris/ $\mathrm{HCl}$ (pH 8.0), $2 \%$ SDS, $5 \%$ 2-mercaptoethanol, $10 \%(\mathrm{v} / \mathrm{v})$ glycerol, $0.02 \%$ bromophenol blue] were separated electrophoretically through a $12 \%(\mathrm{w} / \mathrm{v})$ resolving gel and a $5 \%(\mathrm{w} / \mathrm{v})$ stacking gel, at a constant current $(8-10 \mathrm{~mA})$ at room temperature for $4 \mathrm{~h}$ in running buffer (25 mM Tris, $192 \mathrm{mM}$ glycine, $0 \cdot 1 \%$ SDS), using an electrophoretic cell (Mini Protein II; Bio-Rad).

165 rDNA sequence analysis. Amplification of the $16 \mathrm{~S}$ rDNA genes of the three novel species described here has been described previously (La Scola et al., 2000). The 16S rDNA nucleotide sequence of $B$. thiooxidans BI- $42^{\mathrm{T}}$ described by Das et al. (1996) is available under GenBank accession no. X81044. Due to discrepancies in the phylogenetic trees obtained by using this sequence, the sequence for $\mathrm{BI}-42^{\mathrm{T}}$ was determined again and has been deposited in GenBank under accession no. AF508803. An evolutionary distance matrix, generated by using DNADIST, was determined using the assumptions of Kimura (1980). A dendrogram was inferred from the evolutionary distances using the neighbour-joining method (Saitou \& Nei, 1987). Bootstrap replications were performed to estimate the reliability of each node of the dendrogram. The bootstrap values were obtained from 1000 randomly generated trees, using the SEQBOOT tool in the PHYLIP package (Felsenstein, 1989).

Analysis of DNA-DNA relatedness. DNA was extracted from the strains and purified as described by Brenner et al. (1972). The procedures for labelling DNA with tritium-labelled nucleotides and for hybridization ( 1 nuclease treatment, trichloroacetic procedure) have been detailed elsewhere (Grimont et al., 1980; Khammas et al., 1989).

Analysis of DNA G+C content. Estimations were performed by HPLC, using a model 46200A system pump (Merck Clevenot). DNA was extracted as described by Ausubel et al. (1995). The denatured DNA solution was mixed with $100 \mu$ nuclease P1 solution (Boehringer) $\left(0 \cdot 1 \mathrm{mg} \mathrm{ml}^{-1}\right.$ in $40 \mathrm{mM}$ sodium acetate buffer containing $2 \mathrm{mM} \mathrm{ZnSO}_{4}, \mathrm{pH} \mathrm{5.3)}$ and incubated at $50{ }^{\circ} \mathrm{C}$ for $1 \mathrm{~h}$. Then, $100 \mu$ l bacterial alkaline phosphatase (Boehringer) solution $\left(0 \cdot 7 \mu \mathrm{l}\right.$ of $2 \cdot 4 \mathrm{U}$ alkaline phosphatase $\mathrm{ml}^{-1}$ in $99 \mu \mathrm{l}$ of $1 \mathrm{M} \mathrm{Tris} / \mathrm{HCl}$ buffer) was added to the mixture and it was incubated at $37^{\circ} \mathrm{C}$ for $1 \mathrm{~h}$. An aliquot $(5 \mu \mathrm{l})$ of the hydrolysate was applied onto a Nucleosil 5C18 Lichrocart column $(4 \times 250 \mathrm{~mm})$ (Merck). Elution was carried out at room temperature using a mixture of $0.2 \mathrm{M}$ $\mathrm{NH}_{4} \mathrm{H}_{2} \mathrm{PO}_{4}(\mathrm{pH} 4 \cdot 5)$ and acetonitrile $(96: 4, \mathrm{v} / \mathrm{v})$. A flow rate of $1 \mathrm{ml} \mathrm{min}{ }^{-1}$ was used and absorbance was monitored at $270 \mathrm{~nm}$. The calibration curve was obtained from a mixture of the four standard nucleotides $\left(5 \mathrm{nmol} \mathrm{ml}^{-1}\right.$ in distilled water) (Sigma). After chromatography, the relative concentration of each nucleotide was calculated on the basis of the peak area in the HPLC elution profile and corrected as described by Tamaoka \& Komagata (1984). Each determination was repeated five times. 
Analysis of whole-cell fatty acid composition. Whole-cell fatty acids were analysed for the three novel species by GC using a 3- to 5 -day-old culture of each strain grown on BCYE agar, as described by Miller \& Berger (1985).

\section{RESULTS AND DISCUSSION}

The results of the biochemical reactions, which allowed differentiation of the strains, are given in Table 2. All analysed strains were Gram-negative, Gimenez-positive, oxidase-positive, catalase-positive (weak reactions) and motile by means of a single polar flagellum. All had urease activity, and grew in NB, on Columbia agar with $5 \%$ sheep blood and $0 \cdot 2 \%$ yeast extract, and at $25,30,35$ and $37^{\circ} \mathrm{C}$. Visible colonies were detectable after $48-72 \mathrm{~h}$ incubation at $30{ }^{\circ} \mathrm{C}$ on BCYE agar. All strains gave negative results in tests for arginine dihydrolase activity, aesculin and gelatin hydrolysis, $\beta$-galactosidase activity and caprate assimilation, acid production by fermentation or oxidation of substrates tested in the API $50 \mathrm{CH}$ system and thiosulphate oxidation. No strain grew in NB with $6 \%$ $\mathrm{NaCl}$. However, strains, even those of the same species, differed in their abilities to grow on Columbia agar with $5 \%$ sheep blood, on MacConkey's agar and at $42{ }^{\circ} \mathrm{C}$. There were also variations in the ability to reduce nitrate and assimilate D-glucose, gluconate, arabinose, D-mannose, mannitol, $\mathrm{N}$ acetyl-D-glucosamine, maltose, adipate, malate, citrate and phenylacetate. B. massiliensis did not grow on MacConkey's agar. B. thiooxidans and B. vestrisii were the only species that assimilated citrate, and B. thiooxidans was the only species that oxidized thiosulphate and which grew weakly at $42{ }^{\circ} \mathrm{C}$. All strains of the same species yielded the same pattern of major protein bands upon SDS-PAGE analysis (Fig. 1). B. massiliensis was characterized by the presence of a $35 \mathrm{kDa}$ protein band and B. eneae by the presence of 32 and $20 \mathrm{kDa}$ protein bands. The three isolates of $B$. vestrisii had indistinguishable protein profiles. All Bosea spp. tested possessed a large amount of $\mathrm{C}_{18: 1 \omega 7 c}$ and also $\mathrm{C}_{16: 1 \omega 7 \mathrm{c}}$

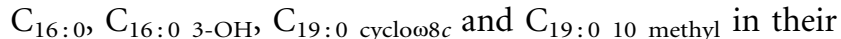
whole-cell fatty acids profiles (Table I, supplementary data; http://ijs.sgmjournals.org). B. thiooxidans was the only species possessing $C_{15: 0}$ and along with $B$. massiliensis the only species possessing $C_{17: 1 \omega 8 c}$ B. massiliensis was characterized by a lack of $C_{17: 0}$ cyclo and $B$. eneae was characterized by a lack of $C_{17: 0}$. Strains 34620 and $34635^{\mathrm{T}}$ of $B$. vestrisii had similar profiles (except for the amount of $C_{19: 0}$ cyclow8c present), whereas the profile of $B$. vestrisii 63286 was considerably different. The MIC values for most antibacterials tested were found to be high. B. massiliensis was the most susceptible species and the only species with a low MIC value for ticarcillin (Table II, supplementary data; http://ijs.sgmjournals.org). All of the Bosea spp. tested were characterized by a high susceptibility to doxycycline, with MIC values of $\leqslant 0.5 \mathrm{mg} \mathrm{l}^{-1}$, with the exception of $B$. eneae $34614^{\mathrm{T}}$. Due to their proximity to immunocompromised patients and their fastidious nature, we can speculate that the novel species described here could be responsible for undiagnosed cases of hospital-acquired pulmonary infections,

Table 2. Biochemical reactions of Bosea spp.

Strains: 1, B. thiooxidans; 2, B. massiliensis $63287^{\mathrm{T}}$; 3, B. massiliensis $34649 ; 4$, B. vestrisii $63286 ; 5$, B. vestrisii $34635^{\mathrm{T}} ; 6$, B. vestrisii $34620 ; 7$, B. eneae $34614^{\mathrm{T}}$; 8 , B. eneae 34617 . + , Positive reaction; $+^{\mathrm{w}}$, weak reaction; -, negative reaction.

\begin{tabular}{|c|c|c|c|c|c|c|c|c|}
\hline Test & 1 & 2 & 3 & 4 & 5 & 6 & 7 & 8 \\
\hline Growth on Columbia agar with $5 \%$ sheep blood & + & - & $+{ }^{\mathrm{w}}$ & + & $+{ }^{\mathrm{w}}$ & + & $+{ }^{\mathrm{w}}$ & $+{ }^{\mathrm{w}}$ \\
\hline $\begin{array}{l}\text { Haemolysis on Columbia agar with } 5 \% \text { sheep } \\
\text { blood and } 0 \cdot 2 \% \text { yeast extract }\end{array}$ & $+{ }^{\mathrm{w}}$ & $+{ }^{\mathrm{w}}$ & $+{ }^{\mathrm{w}}$ & + & $+{ }^{\mathrm{w}}$ & + & $+{ }^{\mathrm{w}}$ & $+{ }^{\mathrm{w}}$ \\
\hline Growth on MacConkey's agar & + & - & - & + & + & + & $+{ }^{\mathrm{w}}$ & + \\
\hline Growth at $42{ }^{\circ} \mathrm{C}$ & $+{ }^{\mathrm{w}}$ & - & - & - & - & - & - & - \\
\hline Thiosulphate oxidation & + & - & - & - & - & - & - & - \\
\hline Nitrate reduction & + & + & - & - & - & + & - & - \\
\hline \multicolumn{9}{|l|}{ Assimilation of: } \\
\hline D-Glucose & + & - & - & - & + & + & - & - \\
\hline Arabinose & + & - & - & - & + & + & - & - \\
\hline Mannose & + & - & - & - & + & + & - & - \\
\hline Mannitol & + & - & - & - & + & + & - & - \\
\hline$N$-Acetyl-D-glucosamine & + & - & - & - & + & + & - & - \\
\hline Maltose & + & - & - & - & + & + & - & - \\
\hline Gluconate & + & + & - & + & + & + & + & - \\
\hline Adipate & + & + & - & - & + & + & + & - \\
\hline Malate & + & + & - & + & + & + & - & - \\
\hline Citrate & + & - & - & + & + & + & - & - \\
\hline Phenylacetate & + & - & - & + & - & - & - & - \\
\hline DNA G+C content $(\mathrm{mol} \%)$ & $68 \cdot 2$ & $66 \cdot 7$ & $67 \cdot 9$ & $67 \cdot 5$ & $65 \cdot 0$ & $65 \cdot 9$ & $69 \cdot 0$ & $67 \cdot 9$ \\
\hline
\end{tabular}




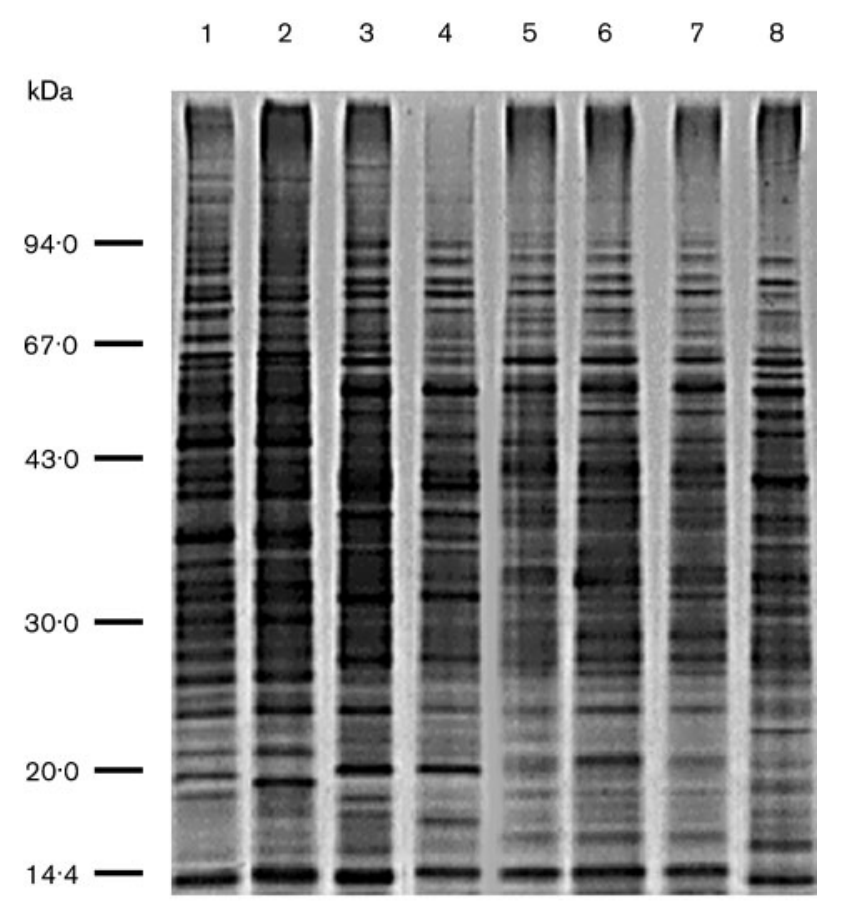

Fig. 1. Silver-stained SDS-PAGE image of whole-cell-protein preparations from Bosea spp. Lanes: 1, B. massiliensis $63287^{\top}$; 2, B. massiliensis $34649 ; 3, B$. eneae $34614^{\top} ; 4, B$. eneae 34617 ; 5 , B. vestrisii $63286 ; 6$, B. vestrisii $34635^{\top} ; 7$, B. vestrisii $34620 ; 8, B$. thiooxidans $\mathrm{BI}-42^{\top}$.

just as Legionella spp. are responsible for nosocomial pneumonia. If such a scenario were true, it is important to note the high susceptibility of the Bosea spp. to doxycycline.

The DNA G+C contents of the Bosea spp. ranged from 65 to $69 \mathrm{~mol} \%$. Phylogenetic relationships inferred from a comparison of the $16 \mathrm{~S}$ rRNA gene sequences showed that the Bosea spp. and Methylobacterium mesophilicum formed a cluster that was separate from Afipia spp., Nitrobacter spp. and Bradyrhizobium spp. The Bosea spp. were also wellseparated from M. mesophilicum (Fig. 2). Bootstrap values for the distributions of the four Bosea species were all greater than $800 / 1000$. In spite of this clustering, we found in our first comparison of the 16S rDNA sequences of the Bosea spp. that the sequence similarity between $B$. thiooxidans BI$42^{\mathrm{T}}$ and the three novel species of Bosea, using the sequence deposited by Das et al. (1996), was approximately $92 \%$. A new determination of the $16 \mathrm{~S}$ rDNA sequence of $B$. thiooxidans $\mathrm{BI}-42^{\mathrm{T}}$ allowed us to discover that there is an error in the original sequence deposited in GenBank (accession no. X81044). In the original sequence, $50 \mathrm{bp}$ were omitted (positions 277-331 of the new sequence; GenBank accession no. AF508803). Among the Bosea spp., sequence similarity values ranged from $98 \cdot 32$ to $99 \cdot 86 \%$ (Table III, supplementary data; http://ijs.sgmjournals.org) using the corrected sequence. The most closely related species were found to be B. eneae and B. vestrisii. DNA-DNA hybridization data confirmed that $B$. thiooxidans, B. eneae,

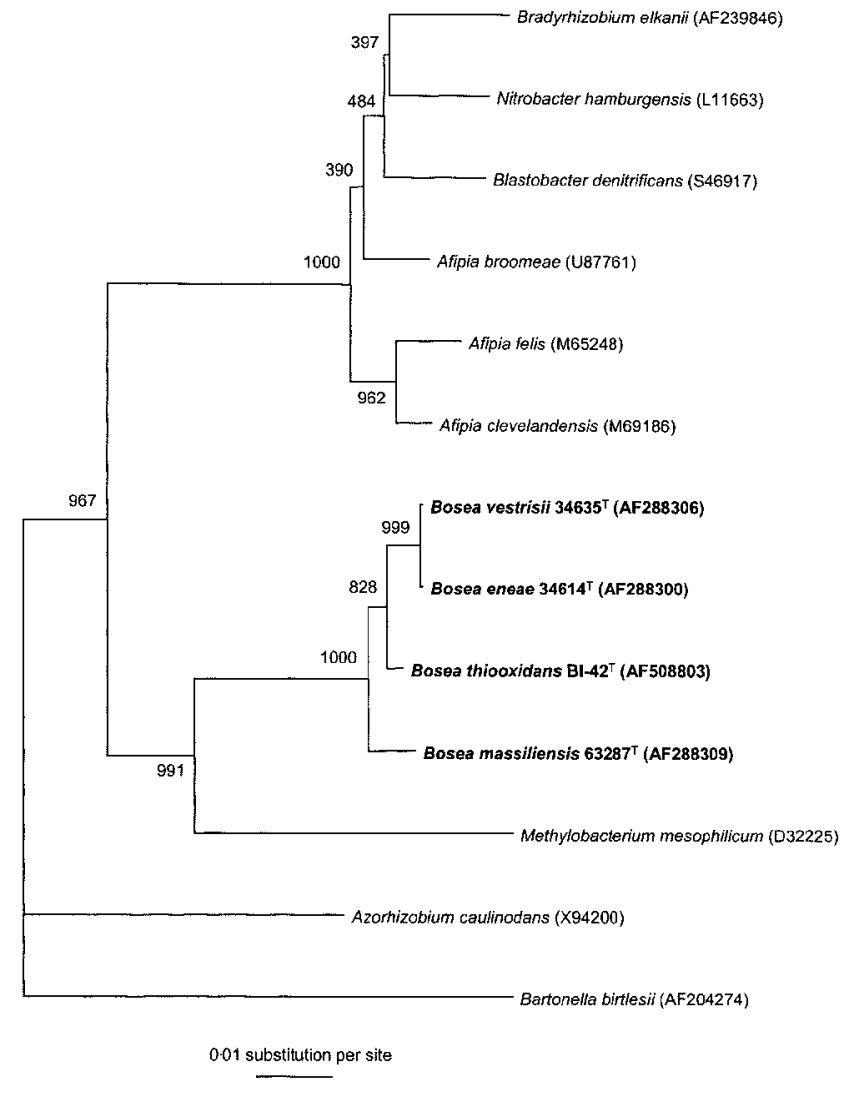

Fig. 2. Dendrogram depicting the phylogenetic relationships between Bosea spp., within the Bradyrhizobium group of the $\alpha$-Proteobacteria. The tree was derived from a comparison of 1381 bases of the $16 \mathrm{~S}$ rDNA sequences. The support for each node of the tree, as determined by bootstrap resampling (1000 replications), is shown. Nucleotide accession numbers for the sequences used to construct this dendrogram are given in parentheses.

B. vestrisii and B. massiliensis were distinct species (Table 3). As described previously for several species, including Bacillus spp. (Ash et al., 1991; Fox et al., 1992), the study of $16 \mathrm{~S} \mathrm{rDNA}$ sequences alone may not be sensitive enough to discriminate confidently between groups of bacteria; therefore, these data must be accompanied by DNA-DNA hybridization data for accurate analyses to be made (Stackebrandt \& Goebel, 1994). Indeed, species definition must be based on the results of DNA-DNA hybridization and phenotypic data (Wayne et al., 1987; Grimont, 1998). Interestingly, the original description of the genus Bosea included thiosulphate oxidation, but this feature appears to be specific to $B$. thiooxidans and thus can be used to differentiate it from the novel species described herein. For the genus Bosea, the value of biochemical reactivity as a species identifier should be interpreted with caution, as different strains of the same species yielded different results. Only antibacterial susceptibility and SDS-PAGE analysis of proteins were found to be reliable phenotypic delineators for the Bosea spp. examined here. As the comparison of $16 \mathrm{~S}$ 
Table 3. DNA relatedness among Bosea spp.

Strains: 1 , B. thiooxidans BI- $42^{\mathrm{T}} ; 2$, B. massiliensis $63287^{\mathrm{T}} ; 3, B$. eneae $34614^{\mathrm{T}} ; 4, \quad$ B. vestrisii $34635^{\mathrm{T}} ; \quad 5, \quad B$. vestrisii 63286 . Relatedness values are shown as percentages; $\Delta T_{\mathrm{m}}$ values $\left({ }^{\circ} \mathrm{C}\right)$ are given in parentheses. ND, Not done.

\begin{tabular}{|lrcrrr|}
\hline Strain & $\mathbf{1}$ & $\mathbf{2}$ & $\mathbf{3}$ & $\mathbf{4}$ & \multicolumn{1}{c|}{$\mathbf{5}$} \\
\hline B. thiooxidans $\mathrm{BI}-42^{\mathrm{T}}$ & 100 & $\mathrm{ND}$ & 7 & $\mathrm{ND}$ & $\mathrm{ND}$ \\
B. massiliensis $63287^{\mathrm{T}}$ & 8 & 100 & 17 & 12 & 12 \\
B. massiliensis 34649 & 14 & $71(1 \cdot 1)$ & 15 & 12 & 14 \\
B. eneae $34614^{\mathrm{T}}$ & 16 & 14 & 100 & 42 & 38 \\
B. eneae 34617 & 11 & 12 & $79(0 \cdot 3)$ & 43 & 39 \\
B. vestrisii $34635^{\mathrm{T}}$ & 13 & 12 & 31 & 100 & 79 \\
B. vestrisii 34620 & 13 & 13 & 35 & $100(0 \cdot 6)$ & 78 \\
B. vestrisii 63286 & 12 & 17 & 39 & $70(0 \cdot 7)$ & 100 \\
\hline
\end{tabular}

rDNA sequences is not sensitive enough for the reliable delineation of Bosea spp., comparison of sequences from a more divergent part of the genome, such as the rrs-rrl intergenic spacer, may be more suitable. This approach has already been used for other members of the $\alpha$-Proteobacteria, including Nitrobacter spp. (Grundmann et al., 2000) and Bradyrhizobium spp. (van Berkum \& Fuhrmann, 2000).

\section{Emended description of the genus Bosea (Das et al. 1996)}

Bosea (Bos'e.a. N.L. gen. n. Bosea of J. C. Bose, the founder of the Bose Institute, where the type species Bosea thiooxidans was isolated).

Members of the genus are Gram-negative, but stain well with Gimenez stain, oxidase-positive, catalase-positive rods in the $\alpha-2$ subgroup of the Proteobacteria. Motile by means of a single polar or subpolar flagellum. Grow on BCYE agar, in NB and weakly on Columbia agar with $5 \%$ sheep blood, but not in $\mathrm{NB}$ containing $6 \% \mathrm{NaCl}$. Colonies are smooth, mucoid, round and cream coloured. Grow well at 25 and $37^{\circ} \mathrm{C}$. Urease-positive and $\alpha$-haemolytic on Columbia agar containing $5 \%$ sheep blood and $0 \cdot 2 \%$ yeast extract. Negative in assays for arginine dihydrolase activity, aesculin and gelatin hydrolysis, $\beta$-galactosidase activity and maltose assimilation, and in assays for acid production by fermentation or oxidation of substrates tested in the API $50 \mathrm{CH}$ system, especially D-glucose, D-fructose, D-mannose and sucrose. Have high MIC values for penicillin and amoxicillin and low MIC values for doxycycline. The most abundant fatty acid is cis-octadec-9-anoic acid $\left(\mathrm{C}_{18: 1 \omega 7 c}\right)$. DNA G+C content is $64 \cdot 2-65 \mathrm{~mol} \%$. The type species is Bosea thiooxidans.

\section{Description of Bosea eneae sp. nov.}

Bosea eneae (e.ne'ae. N.L. gen. n. eneae of Enea, to honour Maryse Enea, a technician in the Unité des Rickettsies, for her many contributions to the isolation of obligate intracellular bacteria, especially Rickettsiaceae).
Exhibits all of the characteristics of the genus, growing on MacConkey's agar and Columbia agar with $5 \%$ sheep blood, in co-cultivation with Acanthamoeba polyphaga in Page's amoebal saline, but not at $42{ }^{\circ} \mathrm{C}$. Does not reduce nitrate or oxidize thiosulphate, and gives variable reactions for the assimilation of gluconate and adipate. Biochemical characteristics of use in differentiating this species from other species of Bosea are given in Table 2 . The whole-cell fatty acids profile of the species is given in Table I (supplementary data). The antimicrobial susceptibility profile of the species is given in Table II (supplementary data) and is characterized only by the low MIC value for doxycycline. DNA G+C content is $67 \cdot 9-69 \mathrm{~mol} \%$. Isolated from the water supply of the La Timone Hospital Centre (Marseilles, France). The type strain of Bosea eneae is $34614^{\mathrm{T}}(=\mathrm{CIP}$ $106338^{\mathrm{T}}=$ CCUG $43111^{\mathrm{T}}$ ).

\section{Description of Bosea massiliensis sp. nov.}

Bosea massiliensis (mas.si.li.en'sis. L. adj. massiliensis pertaining to Massilia, the ancient Roman name of Marseille, France, where the organism was isolated).

Exhibits all of the characteristics of the genus, growing well in co-cultivation with Acanthamoeba polyphaga in Page's amoebal saline, but does not grow at $42{ }^{\circ} \mathrm{C}$ or on MacConkey's agar. Does not oxidize thiosulphate and gives variable reactions for nitrate reduction and assimilation of gluconate, malate and adipate. Biochemical characteristics of use in differentiating this species from other species of Bosea are given in Table 2. The whole-cell fatty acids profile of the species is given in Table I (supplementary data). The antimicrobial susceptibility profile of the species is given in Table II (supplementary data) and is characterized by the lower MIC values to most antibiotics compared to other species of Bosea. DNA G+C content is $66 \cdot 7-67 \cdot 9 \mathrm{~mol} \%$. Isolated from the water supply of the La Timone Hospital Centre (Marseilles, France). The type strain of Bosea massiliensis is $63287^{\mathrm{T}}(=\mathrm{CIP}$ $106336^{\mathrm{T}}=$ CCUG $43117^{\mathrm{T}}$ ).

\section{Description of Bosea vestrisii sp. nov.}

Bosea vestrisii (ves.tri'si.i. N.L. gen. n. vestrisii of Vestris, to honour Guy Vestris, a technician in the Unite des Rickettsies, for his many contributions to the isolation of obligate intracellular bacteria, especially Rickettsiaceae).

Exhibits all of the characteristics of the genus, growing on MacConkey's agar, Columbia agar with $5 \%$ sheep blood and in co-cultivation with Acanthamoeba polyphaga in Page's amoebal saline, but not at $42{ }^{\circ} \mathrm{C}$. Does not oxidize thiosulphate and gives variable reactions for nitrate reduction. Biochemical characteristics of use in differentiating this species from other species of Bosea are given in Table 2. The whole-cell fatty acids profile of the species is given in Table I (supplementary data). The antimicrobial susceptibility profile of the species is given in Table II (supplementary data) and is characterized by the low 
MIC values for doxycycline and netilmicin. DNA G+C content is $65-67 \cdot 5 \mathrm{~mol} \%$. Isolated from the water supply of the La Timone Hospital Centre (Marseilles, France). The type strain of Bosea vestrisii is $34635^{\mathrm{T}}\left(=\mathrm{CIP} 106340^{\mathrm{T}}\right.$ $=$ CCUG $43114^{\mathrm{T}}$ ).

\section{ACKNOWLEDGEMENTS}

The authors are indebted to Lina Barrassi and Elisabeth Ageron for their technical help, and to Richard J. Birtles and Kelly Johnston for reviewing the manuscript.

\section{REFERENCES}

Ash, C., Farrow, J. A., Dorsch, M., Stackebrandt, E. \& Collins, M. D. (1991). Comparative analysis of Bacillus anthracis, Bacillus cereus, and related species on the basis of reverse transcriptase sequencing of $16 \mathrm{~S}$ rRNA. Int J Syst Bacteriol 41, 343-346.

Ausubel, F. M., Brent, R., Kingston, R. E., Moore, D. D., Seidman, J. G., Smith, J. A. \& Struhl, K. (editors) (1995). Current Protocols in Molecular Biology, pp. 2.2.1-2.4.5. New York: Wiley.

Brenner, D. J., Fanning, G. R., Rake, A. V. \& Johnson, K. E. (1972). Polynucleotide sequence divergence among strains of Escherichia coli and closely related organisms. J Bacteriol 109, 953-965.

Das, S. K., Mishra, A. K., Tindall, B. J., Rainey, F. A. \& Stackebrandt, E. (1996). Oxidation of thiosulfate by a new bacterium, Bosea thiooxidans (strain BI-42) gen. nov., sp. nov.: analysis of phylogeny based on chemotaxonomy and $16 \mathrm{~S}$ ribosomal DNA sequencing. Int J Syst Bacteriol 46, 981-987.

Felsenstein, J. (1989). PHYLIP - Phylogeny inference package (version 3.2). Cladistics 5, 164-166.

Fox, G. E., Wisotzkey, J. D. \& Jurtshuk, P., Jr (1992). How close is close: $16 \mathrm{~S}$ rRNA sequence identity may not be sufficient to guarantee species identity. Int J Syst Bacteriol 42, 166-170.

Grimont, P. A. D. (1998). Use of DNA reassociation in bacterial classification. Can J Microbiol 34, 541-546.
Grimont, P. A. D., Popoff, M. Y., Grimont, F., Coynault, C. \& Lemelin, M. (1980). Reproducibility and correlation study of three deoxyribonucleic acid hybridization procedures. Curr Microbiol 4, 325-330.

Grundmann, G. L., Neyra, M. \& Normand, P. (2000). High-resolution phylogenetic analysis of $\mathrm{NO}_{2}$-oxidizing Nitrobacter species using the rrs-rrl IGS sequence and rrlgenes. Int J Syst Evol Microbiol 50, 1893-1898.

Khammas, K. M., Ageron, E., Grimont, P. A. D. \& Kaiser, P. (1989). Azospirillum irakense sp. nov., a nitrogen-fixing bacterium associated with rice roots and rhizosphere soil. Res Microbiol 140, 679-693.

Kimura, M. (1980). A simple method for estimating evolutionary rate of base substitutions through comparative studies of nucleotide sequences. J Mol Evol 16, 111-120.

La Scola, B., Barrassi, L. \& Raoult, D. (2000). Isolation of new fastidious $\alpha$-Proteobacteria and Afipia felis from hospital water supplies by direct plating and amoebal co-culture procedures. FEMS Microbiol Ecol 34, 129-137.

Laëmmli, U. K. (1970). Cleavage of structural proteins during the assembly of the head of bacteriophage T4. Nature 227, 680-685.

Miller, L. \& Berger, T. (1985). Bacterial identification by gas chromatography of whole cell fatty acids. Avondale, PA: HewlettPackard.

Saitou, N. \& Nei, M. (1987). The neighbor-joining method: a new method for reconstructing phylogenetic trees. Mol Biol Evol 4, 406-425.

Stackebrandt, E. \& Goebel, B. M. (1994). Taxonomic note: a place for DNA-DNA reassociation and 16S rRNA sequence analysis in the present species definition in bacteriology. Int J Syst Bacteriol 44, 846-849.

Tamaoka, J. \& Komagata, K. (1984). Determination of DNA base composition by reversed-phase high-performance liquid chromatography. FEMS Microbiol Lett 25, 125-128.

van Berkum, P. \& Fuhrmann, J. J. (2000). Evolutionary relationships among the soybean bradyrhizobia reconstructed from 16S rRNA gene and internally transcribed spacer region sequence divergence. Int J Syst Evol Microbiol 50, 2165-2172.

Wayne, L. G., Brenner, D. J., Colwell, R. R. \& 9 other authors (1987). International Committee on Systematic Bacteriology. Report of the ad hoc committee on reconciliation of approaches to bacterial systematics. Int J Syst Bacteriol 37, 463-464. 